Published in final edited form as:

J Investig Med. 2013 August ; 61(6): 950-955. doi:10.231/JIM.0b013e3182946b69.

\title{
Natriuretic Peptides as Biomarkers in Heart Failure
}

\author{
James L. Januzzi Jr, MD \\ Cardiology Division, Massachusetts General Hospital, Boston MA
}

\begin{abstract}
Following the initial discovery of a natriuretic and diuretic peptide factor present in atrial myocardial tissue homogenates, subsequent elucidation of the natriuretic peptide family has led to substantial advances in the understanding of the autocrine, paracrine, and endocrine regulation of the cardiovascular system. Furthermore, with the development of assays for the measurement of the natriuretic peptides, these important biomarkers have gone from being regarded as biological mediators of the cardiovascular system to now represent important clinical tools for the diagnostic and prognostic evaluation of patients with heart failure, and may have potential as a therapeutic target in this setting as well. An historical perspective on the natriuretic peptides from bench to bedside translation will be discussed.
\end{abstract}

\section{Keywords}

natriuretic peptides; biology; diagnosis; prognosis; therapy

Over the past 3 decades, considerable efforts in the study of the natriuretic peptide (NP) family of protein hormones has led a better understanding of the role played by these important substances in the development and complication of various medical conditions, including heart failure (HF). Beyond shedding important light on the complex biological pathways involved in NP-based cardiovascular homeostasis, elucidation of NP biology has also led to the development of sensitive immunoassays for their measurement in peripheral blood. Concentrations of ANP and BNP in particular have been deeply studied for their role in a host of diagnoses, including HF, with results demonstrating utility for these biomarkers as tools to establish diagnosis, understand prognosis, and ultimately potentially serving as a target for therapy. This discussion will examine the historical background of the NP family, specifically focusing on ANP and BNP, with a discussion of their biology, and how these peptides may be clinically utilized.

\section{History of the Natriuretic Peptides}

Following very early electron microscopy studies in the 1950's revealing dense granules comparable to those found in glandular tissue located in the atrial myocardium, a consensus

Correspondence: James L. Januzzi, Jr, MD, Cardiology Division, Massachusetts General Hospital, Yawkey 5984, 55 Fruit Street, Boston, MA, 02114, P: 617-726-3443, F: 617-643-1620, jjanuzzi@ partners.org.

Presented at: Experimental Biology 2013

Disclosures: Dr. Januzzi has received grant support from Roche Diagnostics, Siemens AG, BG Medicine, Thermo Fisher, and Critical Diagnostics. 
developed around the concept of the heart as an endocrine organ. The seminal work of Adolfo de Bold in 1981 led to the discovery of ANP; following observations that the presence and density of atrial granules changed with intravascular volume, experiments were performed where intravenous injection of atrial myocardial extracts led to a rapid diuretic and natriuretic response in rats. Subsequent isolation and identification of the peptides responsible for this effect led to the first descriptions of the NP family.

\section{Evolution of the Natriuretic Peptide Family}

The natriuretic peptide (NP) family is believed to have evolved for the common homeostatic purpose of volume, osmosis and pressure regulation of the circulatory system. More recently, evidence supports the concept that this family of cardiovascular peptides has also played an autocrine and paracrine role in the control of myocardial structure and function as well $[1,2]$. The known NP system in human and non-human vertebrates consists of at least six “cardiovascular" peptides ANP, BNP, CNP, DNP and VNP as well as a "renal" NP, urodilatin. While each member of the NP family appears to exert vaso- or venodilator effects and may induce diuresis and natriuresis, the relative balance of these effects varies somewhat from peptide to peptide.

The NP system is phylogenetically preserved with both components (endocrine and paracrine) identified in the heart and brain of a wide range of species, including teleost fish, amphibians, reptiles, birds and selected species of mammals (human, cat, cattle, dog, mouse, rat, sheep and swine) [3]. Across all species, CNP is the most structurally conserved member of the NP family [3], while BNP and its amino-terminal pro-segment NT-proBNP differ even between mammalian species [3]; as such the human BNP $5^{\prime}$ flanking sequence (FS) is $65 \%$ and $77 \%$ homologous with the rat and mouse BNP genes, respectively, while the rodent proximal promoters are greater than $90 \%$ homologous [4]. It has been suggested that the NP system evolved from being sodium-extruding hormones in fish to volume depleting hormones in tetrapods [5].

Downstream biologic effects of the NPs are well-known; in the case of ANP and BNP, these include vasodilation, natriuresis, and diuresis; in addition, BNP may down-regulate the renin-angiotensin aldosterone system. BNP may have an anti-fibrotic effect on the heart muscle [6] as the phenotype of BNP "knockout" mice is one of myocardial fibrosis with abnormal remodeling in the setting of ventricular pressure overload [6]. Lastly, BNP also appears to possess pro-lusitropic properties [7].

\section{ANP and BNP Tissue Expression}

Notable stimuli for ANP and BNP gene expression, transcription and translation include mechanical stretch [8, 9], ischemic injury/hypoxia [10], endothelin-1 [11], angiotensin II [12], interleukin-1 $\beta$ [13], and $\alpha$ and $\beta$ adrenergic agonists [13] among others.

The great majority of ANP is synthesized and stored in atrial tissue. In contrast, while BNP appears to be more abundant in the atria than in the ventricles, given the greater ventricular mass, $70 \%$ of all cardiac BNP derives from the ventricles under normal conditions and up to $88 \%$ under pathophysiologic conditions [14]. Additionally, in contrast to ANP, most BNP is 
synthesized in bursts of activation from physiologic stimuli [15], and 'emergently' increased when peptide secretion is called upon, rather than being stored.

Extra-cardiac sources of BNP in humans have been found in brain, lungs, kidneys, aorta and adrenal glands at much smaller concentrations [16]. As such, the majority of BNP gene expression in mammals has been found to be in the heart, with extra-cardiac BNP expression being more species-specific, and in all cases much lower than cardiac levels [17].

\section{Natriuretic peptide processing and secretion}

Each NP gene produces a pro-hormone from which the active peptide is generated. In the case of ANP, an initial 126 amino acid precursor is cleaved to yield a 96 amino acid Nterminal pro-peptide, and a 28 amino acid C-terminal fragment. The latter peptide is biologically active, with an extremely short half life after secretion, due to degradation. It remains yet unclear if uncleaved proANP ${ }_{1-126}$ circulates in any significant amount.

Following translation of the BNP gene, an initial gene product is produced, preproBNP $_{1-134}$. This peptide undergoes rapid removal of a 26 amino acid signal peptide, which results in the formation of a 108 amino acid pro-hormone, proBNP ${ }_{1-108}$ [18]. Subsequently, proBNP ${ }_{1-108}$ is cleaved by proteolytic enzymes furin [19] and corin [20] to release two portions: a 76 amino acid amino-terminal portion, NT-proBNP ${ }_{1-76}$, and the biologically active 32 -amino-acid molecule $\mathrm{BNP}_{1-32}$, which possesses a characteristic 17amino acid disulfide bound ring essential for biological activity.

A substantial shift in the understanding of NP secretion has occurred in recent years. Early studies using radioimmunoassays to evaluate BNP in HF actually suggested the presence of both high and low molecular weight forms of "BNP", with high molecular weight BNP being the major component (mean ratio, 1.9:1). [21]. More recent studies have used Western blot analysis techniques to better characterize these immunoreactive BNP species in HF plasma, and have confirmed that there are both low molecular weight BNP forms (similar to $\mathrm{BNP}_{1-32}$ ) and higher molecular-weight forms of BNP similar to recombinant proBNP ${ }_{1-108}[22]$. Regarding NT-proBNP, since the N-terminal region of proBNP ${ }_{1-108}$ contain sequences permitting oligomerization, a trimer of $\mathrm{NT}^{-}$proBNP $_{1-76}$ has been described [23]. Also, fragmentation of NT-proBNP ${ }_{1-76}$ occurs since proteolysis can exist at both carboxy- and amino-terminal ends of the molecule [24]. Therefore, a number of molecules larger and smaller than NT-proBNP ${ }_{1-76}$ are present in the circulation. Lastly, NTproBNP is variably glycosylated [25].

\section{Natriuretic Peptide Clearance}

In the case of ANP and BNP, important mechanisms of removal from circulation include receptor-mediated clearance, enzymatic degradation, and passive removal. Biologically inactive pro-peptides from both are cleared passively.

There are at least three types of NP receptors: NPR-A and NPR-B (the guanylyl cyclasecoupled receptors responsible for biologic effects) as well as NPR-C, the short cytoplasmic domain receptor, responsible for peptide clearance and possibly regulation of cell 
proliferation. Enzymatic degradation of the NPs is carried out by several peptides, including neutral endopeptidases, dipeptidyl-peptidase IV [26] as well as by the peptidase meprin A, which is expressed in the kidney [27]. Passive removal from the blood stream is an important mode of NP metabolism. Several organs with high blood flow have been shown to clear BNP and NT-proBNP, for example, including the musculature, liver, spleen, brain, lungs, and kidneys [28]. The relative contribution of the kidneys to removal of BNP and NTproBNP from the blood stream remains extremely controversial. The results of carefully performed mechanistic studies suggest that the renal extraction ratio of both BNP and NTproBNP is equivalent, and only about $15-20 \%$ [29].

\section{Natriuretic Peptide Assays}

The understanding of ANP and BNP biology has substantial importance relative to the development and understanding of assays for their measurement. For example, following many years of attempting to reliably measure ANP, it became clear that a novel approach was needed due to the lability of the protein. Accordingly, an immunoassay directed against the mid-region of proANP ${ }_{1-96}$ (MR-proANP) has been developed, which has been shown to be useful for quantifying circulating ANP as a surrogate.

Based on the discussion above, it is understandable that currently-available commercial assays for detection of "NT-proBNP ${ }_{1-76}$ " or " $\mathrm{BNP}_{1-32}$ " actually measure more than the individual peptides: in the case of NT-proBNP, assays likely are detecting NT-proBNP ${ }_{1-76}$ plus variable amounts of proBNP $1-108$. For $\mathrm{BNP}$, conventional assays likely detect various degradation products of $\mathrm{BNP}_{1-32}$, including $\mathrm{BNP}_{3-32}$ in addition to intact proBNP ${ }_{1-108}$ [22]. Despite this fact, assays for the measurement of both NT-proBNP and BNP have been shown to be of considerable utility for clinical evaluation of HF.

\section{Clinical Applications: Natriuretic Peptides to Diagnose HF}

Many patients presenting with acute dyspnea (including those with acutely decompensated HF [ADHF]) have multiple co-existing medical disorders that may complicate their diagnosis and management. Diagnostic uncertainty in the setting of acute dyspnea is associated with longer hospital length of stay, more diffuse diagnostic and therapeutic efforts, increased health-care costs, and higher likelihood for repeat HF hospitalization or death [30]. It is in this context that the clinical value around the use of NP assays has developed. The addition of testing for MR-proANP, BNP or NT-proBNP to standard clinical assessment has been shown to be valuable for an accurate and efficient diagnosis and prognostication of HF, and the use of BNP or NT-proBNP may be associated with improved clinical outcomes [31].

Concentrations of MR-proANP, BNP, and NT-proBNP are increased in HF and correlate well with ventricular wall stress and severity of HF [32,33]. The Breathing Not Properly [33] and Pro-BNP Investigation of Dyspnea in the Emergency Department (PRIDE) [32] studies first showed that NP levels were more accurate for diagnosis or exclusion of ADHF than clinical judgment, particularly in the context of diagnostic uncertainty [34]. When added to comprehensive clinical assessment, BNP or NT-proBNP are both incrementally useful for diagnosis of ADHF, and are both endorsed in current practice guidelines for $\mathrm{HF}$ 
evaluation (particularly when diagnostic indecision is present). Subsequently, the Biomarkers in Acute Congestive Heart Failure and PRIDE studies showed diagnostic value to MR-proANP [35, 36]. Interestingly in both studies concentrations of MR-proANP appear to be additive to BNP or NT-proBNP for the diagnosis of ADHF, suggesting contribution of different pathologies to their release.

Elevated NP concentrations are powerfully associated with the presence of HF; however, there is no value for any NP assay that is $100 \%$ diagnostic for the diagnosis. Indeed, MRproANP as well as BNP/NT-proBNP may be elevated by structural heart disease of many sorts (Table 1), may be abnormal in non-cardiac syndromes (Table 2), and patient factors may variably influence results further (Table 3 ).

While experience with MR-proANP is limited outside of acute dyspnea evaluation, abundant data are now available showing that both BNP and NT-proBNP may be useful in the differential diagnosis of dyspnea in less acute settings, such as in primary care. In this context, values for both peptides supplement clinical judgment and are particularly useful to exclude the diagnosis of HF in those with very low concentrations of BNP/NT-proBNP.

\section{Natriuretic Peptides and Prognosis in HF}

Across all stages of HF, elevated NP concentrations are at least comparable prognostic predictors of mortality and cardiovascular events relative to traditional predictors of outcome in this setting, with higher values predicting worse prognosis in a linear fashion. For example, in very complex analyses designed with a goal to produce the most parsimonious prognostic model, NT-proBNP was among the strongest long-term prognostic variables in the PRIDE study [37]. This prognostic value may be used to stratify patients at the highest risk of adverse outcomes. Interestingly, in analogy to its additive value with BNP or NT-proBNP to identify HF, concentrations of MR-proANP also appear to add to prognostic models even in the presence of either BNP or NT-proBNP [36].

A unique value of the NPs for prognosis is the ability to measure them serially to provide dynamic prognostic information. For example, in ADHF, an initial value of BNP or NTproBNP is prognostically useful. However, a follow-up measurement after therapy provides incremental prognostic value.

Observational studies suggest that when BNP/NT-proBNP concentrations decrease substantially during hospitalization, a better prognosis is expected compared with those that fail to decrease or actually increase their values [38]. In a similar fashion, in patients with ambulatory HF, serial concentrations of BNP or NT-proBNP inform incremental prognostic information to a baseline value: those with rising concentrations of either peptide over time have a worse prognosis than those with a low or falling pattern [39]. Adverse events predicted by the NPs include death, as well as HF hospitalization, cardiac arrhythmias such as ventricular tachycardia and atrial fibrillation, as well as worsening ventricular function due to progressive myocardial remodeling.

A curious link between NP concentrations and therapies for HF exists. It is now wellrecognized that therapies with benefits for HF may result in a reduction in concentrations of 
NP relative to their benefits. For example, loop diuretics result in potent diuresis and reduction in myocardial stretch (itself an important trigger for NP secretion); in this context, reductions in NP concentrations typically follow the clinical decongestion of the patient. Beyond diuretics—which have little benefit beyond symptomatic relief of HF-several other classes of drugs (each with potent prognostic benefit in HF; Table 4) have been shown to reduce values of BNP and NT-proBNP (few data are available regarding MR-proANP). In light of this link, the use of BNP or NT-proBNP as a target of HF therapy is a testable hypothesis recently explored.

\section{Natriuretic Peptides for Guided Management of HF}

The concept of using BNP or NT-proBNP as a "guide" to HF management is not new, but clarity about the appropriate means by which to implement the approach has been gained in recent years. Important concepts needed to support correct application of NP guided HF care included the identification of the "target value" for either peptide, an understanding of biological variability for each, as well as the appropriate timing for re-sampling when measuring them serially.

As is implied above, concentrations of BNP or NT-proBNP rise in proportion to the risk in $\mathrm{HF}$, and there is no concentration above the very low values seen in healthy individuals that is reassuring. However, consensus has developed that it is possible to identify BNP or NTproBNP values that may represent an inflection point for risk of HF complications; below these values risk is considerably lower. In the Valsartan Heart Failure Trial, for example a BNP value of $125 \mathrm{pg} / \mathrm{mL}$ and an NT-proBNP value near $1000 \mathrm{pg} / \mathrm{mL}$ provided prognostic value [40]; above these levels, the risk for complications rose monotonically, while below, the risk was low. In other analyses such as the PRIDE study, an NT-proBNP of $1000 \mathrm{pg} / \mathrm{mL}$ again was found to be the appropriate level where risk of HF complications began to rise [41]. It is no surprise, therefore, that HF studies targeting values of BNP or NT-proBNP higher than these concentrations were unsuccessful [42].

Following a therapy alteration, a change in concentration in BNP or NT-proBNP may follow; such changes may be substantial, however it is necessary to understand just how much change in the concentration of either needs to occur in before a definitive change in the biologic milieu determining their levels can be declared. To do so, a better understanding of biological variability is needed. Biological variability is defined as the expected amount of change over time in concentration of any biological measure independent of significant abnormalities in physiology; it is determined by analytical precision of the assays used to measure the peptides (typically $<5 \%$ ) together with the changes in usual physiology of patients with HF. Recent data suggest that week-to-week biological variability of BNP or NT-proBNP to be approximately $30 \%$ in HF patients; changes greater than this amount are to be considered as reflecting a significant change in the abnormal physiology triggering BNP or NT-proBNP release. As well, following a change in therapy, it is worth noting that it may take time to achieve a new steady state of BNP or NT-proBNP transcription and translation; while studies are lacking regarding the time when a nadir in either peptide may occur after a change in therapy, it is known that by 2 to 4 weeks, a lack of significant change in BNP or NT-proBNP is a high risk feature. 
With a good understanding of the factors that underlie appropriate interpretation and response to BNP or NT-proBNP results, it is therefore easy to understand the results of trials that set out to guide HF with a goal to lower BNP or NT-proBNP (Table 5). It is also worthwhile to note that two published meta analyses of the biomarker guided approach to HF care have shown a significant reduction in all-cause mortality [43, 44].

Across each of the published trials, the approach of biomarker guided HF care was welltolerated, without an excess of adverse events associated with the approach. As well, whether successful or not, the added goal of lowering BNP or NT-proBNP resulted in more substantial addition and uptitration of medical therapies, compared to the usual care group in the great majority of trials; in itself, this is an important finding, given the current climate of inadequate $\mathrm{HF}$ care that exists.

In those trials setting out with a goal BNP or NT-proBNP close to the target values articulated above, improved outcomes were observed; in contrast, as noted, those with higher targets were typically neutral. To achieve lower NP targets aggressive care was needed, as shown in the several positive trials where addition and uptitration of HF medications was considerably more assiduous in the NP guided arms [45, 46].

Insight into the benefit of NT-proBNP guided HF care was gained from the recent ProBNP Outpatient Tailored Chronic Heart Failure Therapy (PROTECT) trial [46]. In this small but detailed single center trial, 151 subjects with HF due to left ventricular systolic dysfunction were randomized to receive standard HF care versus standard care plus a goal to reduce NTproBNP $<1000 \mathrm{pg} / \mathrm{mL}$. In this study, substantial uptitration of therapies occurred in both arms, but the NT-proBNP guided patients had significantly more drug therapy changes. In this context, more lowering of NT-proBNP occurred in the biomarker guided arm, with a parallel reduction in adverse outcome. Patients in the biomarker guided arm of the trial had significantly better quality of life compared to the standard care participants [47], and also experienced substantially greater favorable remodeling on their echocardiograms [48]. Conversely, non-responders to HF care in the PROTECT study had worse clinical outcomes, worse quality of life, and more deleterious myocardial remodeling [49].

While in aggregate, or in the case of several studies like PROTECT, the results of NP guided HF studies appear favorable, what is needed at present is a pivotal, prospective multi-center trial to properly inform steps forward with the approach. In 2013, the Guiding Evidence Based Therapy Using Biomarker Intensified Treatment (GUIDE IT; www.clinicaltrials.gov NCT01685840) study initiated enrollment. This multicenter trial of 1100 participants will examine the value of HF therapy with or without a goal of NTproBNP reduction $<1000 \mathrm{pg} / \mathrm{mL}$.

\section{Conclusion}

From their initial discovery as important hormones involved in regulation of various pathways in normal and abnormal physiology including HF, the NP family of proteins has taken on a significant importance in medicine. Both BNP and NT-proBNP are tested world wide for the evaluation and management of patients with suspected or proven HF; recent 
development of a MR-proANP assay has led to encouraging early results with this biomarker. Whether the successes of BNP and NT-proBNP will be repeated or enhanced with MR-proANP remains to be seen. Irrespectively, testing for BNP and NT-proBNP has entirely transformed the diagnostic and prognostic evaluation of patients with a broad range of HF presentations, and their use to better care for patients with HF may further alter the course of modern cardiology.

\section{Acknowledgments}

This symposium was supported in part by a grant from the National Center for Research Resources (R13 RR023236). Dr. Januzzi is supported in part by the Roman W. Desanctis Endowed Distinguished Clinical Scholar Fund.

\section{References}

1. Patel JB, Valencik ML, Pritchett AM, Burnett JC Jr, McDonald JA, Redfield MM. Cardiac-specific attenuation of natriuretic peptide A receptor activity accentuates adverse cardiac remodeling and mortality in response to pressure overload. Am J Physiol Heart Circ Physiol. 2005; 289(2):H77784. [PubMed: 15778276]

2. Tamura N, Ogawa Y, Yasoda A, Itoh H, Saito Y, Nakao K. Two cardiac natriuretic peptide genes (atrial natriuretic peptide and brain natriuretic peptide) are organized in tandem in the mouse and human genomes. J Mol Cell Cardiol. 1996; 28(8):1811-5. [PubMed: 8877790]

3. Takei Y. Does the natriuretic peptide system exist throughout the animal and plant kingdom? Comp Biochem Physiol B Biochem Mol Biol. 2001; 129(2-3):559-73. [PubMed: 11399492]

4. LaPointe MC, Wu G, Garami M, Yang XP, Gardner DG. Tissue-specific expression of the human brain natriuretic peptide gene in cardiac myocytes. Hypertension. 1996; 27(3 Pt 2):715-22. [PubMed: 8613230]

5. Inoue K, Naruse K, Yamagami S, Mitani H, Suzuki N, Takei Y. Four functionally distinct C-type natriuretic peptides found in fish reveal evolutionary history of the natriuretic peptide system. Proc Natl Acad Sci U S A. 2003; 100(17):10079-84. [PubMed: 12893874]

6. Tamura N, Ogawa Y, Chusho H, Nakamura K, Nakao K, Suda M, Kasahara M, Hashimoto R, Katsuura G, Mukoyama M, Itoh H, Saito Y, Tanaka I, Otani H, Katsuki M. Cardiac fibrosis in mice lacking brain natriuretic peptide. Proc Natl Acad Sci U S A. 2000; 97(8):4239-44. [PubMed: 10737768]

7. Yamamoto K, Burnett JC Jr, Redfield MM. Effect of endogenous natriuretic peptide system on ventricular and coronary function in failing heart. Am J Physiol. 1997; 273(5 Pt 2):H2406-14. [PubMed: 9374778]

8. Liang F, Gardner DG. Mechanical strain activates BNP gene transcription through a p38/NFkappaB-dependent mechanism. J Clin Invest. 1999; 104(11):1603-12. [PubMed: 10587524]

9. Pikkarainen S, Tokola H, Majalahti-Palviainen T, Kerkela R, Hautala N, Bhalla SS, Charron F, Nemer M, Vuolteenaho O, Ruskoaho H. GATA-4 is a nuclear mediator of mechanical stretchactivated hypertrophic program. J Biol Chem. 2003; 278(26):23807-16. [PubMed: 12704188]

10. Cameron VA, Rademaker MT, Ellmers LJ, Espiner EA, Nicholls MG, Richards AM. Atrial (ANP) and brain natriuretic peptide (BNP) expression after myocardial infarction in sheep: ANP is synthesized by fibroblasts infiltrating the infarct. Endocrinology. 2000; 141(12):4690-7. [PubMed: $11108284]$

11. He Q, LaPointe MC. Src and Rac mediate endothelin-1 and lysophosphatidic acid stimulation of the human brain natriuretic peptide promoter. Hypertension. 2001; 37(2 Part 2):478-84. [PubMed: 11230322]

12. Wiese S, Breyer T, Dragu A, Wakili R, Burkard T, Schmidt-Schweda S, Fuchtbauer EM, Dohrmann U, Beyersdorf F, Radicke D, Holubarsch CJ. Gene expression of brain natriuretic peptide in isolated atrial and ventricular human myocardium: influence of angiotensin II and diastolic fiber length. Circulation. 2000; 102(25):3074-9. [PubMed: 11120697] 
13. He Q, Wang D, Yang XP, Carretero OA, LaPointe MC. Inducible regulation of human brain natriuretic peptide promoter in transgenic mice. Am J Physiol Heart Circ Physiol. 2001; 280(1):H368-76. [PubMed: 11123253]

14. Mukoyama M, Nakao K, Saito Y, Ogawa Y, Hosoda K, Suga S, Shirakami G, Jougasaki M, Imura H. Human brain natriuretic peptide, a novel cardiac hormone. Lancet. 1990; 335(8692):801-2. [PubMed: 1969551]

15. Yasue H, Yoshimura M, Sumida H, Kikuta K, Kugiyama K, Jougasaki M, Ogawa H, Okumura K, Mukoyama M, Nakao K. Localization and mechanism of secretion of B-type natriuretic peptide in comparison with those of A-type natriuretic peptide in normal subjects and patients with heart failure. Circulation. 1994; 90(1):195-203. [PubMed: 8025996]

16. Gerbes AL, Dagnino L, Nguyen T, Nemer M. Transcription of brain natriuretic peptide and atrial natriuretic peptide genes in human tissues. J Clin Endocrinol Metab. 1994; 78(6):1307-11. [PubMed: 8200930]

17. LaPointe MC. Molecular regulation of the brain natriuretic peptide gene. Peptides. 2005; 26(6): 944-56. [PubMed: 15911064]

18. Sudoh T, Kangawa K, Minamino N, Matsuo H. A new natriuretic peptide in porcine brain. Nature. 1988; 332(6159):78-81. [PubMed: 2964562]

19. Sawada Y, Suda M, Yokoyama H, Kanda T, Sakamaki T, Tanaka S, Nagai R, Abe S, Takeuchi T. Stretch-induced hypertrophic growth of cardiocytes and processing of brain-type natriuretic peptide are controlled by proprotein-processing endoprotease furin. J Biol Chem. 1997; 272(33): 20545-54. [PubMed: 9252368]

20. Yan W, Wu F, Morser J, Wu Q. Corin, a transmembrane cardiac serine protease, acts as a proatrial natriuretic peptide-converting enzyme. Proc Natl Acad Sci U S A. 2000; 97(15):8525-9. [PubMed: 10880574]

21. Yandle TG, Richards AM, Gilbert A, Fisher S, Holmes S, Espiner EA. Assay of brain natriuretic peptide (BNP) in human plasma: evidence for high molecular weight BNP as a major plasma component in heart failure. J Clin Endocrinol Metab. 1993; 76(4):832-8. [PubMed: 8473392]

22. Liang F, O'Rear J, Schellenberger U, Tai L, Lasecki M, Schreiner GF, Apple FS, Maisel AS, Pollitt NS, Protter AA. Evidence for functional heterogeneity of circulating B-type natriuretic peptide. J Am Coll Cardiol. 2007; 49(10):1071-8. [PubMed: 17349887]

23. Seidler T, Pemberton C, Yandle T, Espiner E, Nicholls G, Richards M. The amino terminal regions of proBNP and proANP oligomerise through leucine zipper-like coiled-coil motifs. Biochem Biophys Res Commun. 1999; 255(2):495-501. [PubMed: 10049737]

24. Ala-Kopsala M, Magga J, Peuhkurinen K, Leipala J, Ruskoaho H, Leppaluoto J, Vuolteenaho O. Molecular heterogeneity has a major impact on the measurement of circulating N-terminal fragments of A- and B-type natriuretic peptides. Clin Chem. 2004; 50(9):1576-88. [PubMed: 15265819]

25. Schellenberger U, O'Rear J, Guzzetta A, Jue RA, Protter AA, Pollitt NS. The precursor to B-type natriuretic peptide is an O-linked glycoprotein. Arch Biochem Biophys. 2006; 451(2):160-6. [PubMed: 16750161]

26. Brandt I, Lambeir AM, Ketelslegers JM, Vanderheyden M, Scharpe S, De Meester I. Dipeptidylpeptidase IV converts intact B-type natriuretic peptide into its des-SerPro form. Clin Chem. 2006; 52(1):82-7. [PubMed: 16254193]

27. Pankow K, Wang Y, Gembardt F, Krause E, Sun X, Krause G, Schultheiss HP, Siems WE, Walther T. Successive Action of Meprin A and Neprilysin Catabolizes B-Type Natriuretic Peptide. Circ Res. 2007

28. Palmer SC, Yandle TG, Nicholls MG, Frampton CM, Richards AM. Regional clearance of aminoterminal pro-brain natriuretic peptide from human plasma. Eur J Heart Fail. 2009; 11(9):832-9. [PubMed: 19605456]

29. van Kimmenade RR, Januzzi JL Jr, Bakker JA, Houben AJ, Rennenberg R, Kroon AA, Crijns HJ, van Dieijen-Visser MP, de Leeuw PW, Pinto YM. Renal clearance of B-type natriuretic peptide and amino terminal pro-B-type natriuretic peptide a mechanistic study in hypertensive subjects. J Am Coll Cardiol. 2009; 53(10):884-90. [PubMed: 19264247] 
30. Green SM, Martinez-Rumayor A, Gregory SA, Baggish AL, O’Donoghue ML, Green JA, Lewandrowski KB, Januzzi JL Jr. Clinical Uncertainty, Diagnostic Accuracy, and Outcomes in Emergency Department Patients Presenting With Dyspnea. Arch Intern Med. 2008; 168(7):741748. [PubMed: 18413557]

31. Moe GW, Howlett J, Januzzi JL, Zowall H. N-terminal pro-B-type natriuretic peptide testing improves the management of patients with suspected acute heart failure: primary results of the Canadian prospective randomized multicenter IMPROVE-CHF study. Circulation. 2007; 115(24): 3103-10. [PubMed: 17548729]

32. Januzzi JJL, Camargo CA, Anwaruddin S, Baggish AL, Chen AA, Krauser DG, Tung R, Cameron R, Nagurney JT, Chae CU, Lloyd-Jones DM, Brown DF, Foran-Melanson S, Sluss PM, LeeLewandrowski E, Lewandrowski KB. The N-terminal Pro-BNP Investigation of Dyspnea in the Emergency department (PRIDE) study. The American Journal of Cardiology. 2005; 95(8):948954. [PubMed: 15820160]

33. Maisel AS, Krishnaswamy P, Nowak RM, McCord J, Hollander JE, Duc P, Omland T, Storrow AB, Abraham WT, Wu AH, Clopton P, Steg PG, Westheim A, Knudsen CW, Perez A, Kazanegra R, Herrmann HC, McCullough PA. Rapid measurement of B-type natriuretic peptide in the emergency diagnosis of heart failure. N Engl J Med. 2002; 347(3):161-7. [PubMed: 12124404]

34. Steinhart B, Thorpe KE, Bayoumi AM, Moe G, Januzzi JL Jr, Mazer CD. Improving the Diagnosis of Acute Heart Failure Using a Validated Prediction Model. Journal of the American College of Cardiology. 2009; 54(16):1515-1521. [PubMed: 19815122]

35. Maisel A, Mueller C, Nowak R, Peacock WF, Landsberg JW, Ponikowski P, Mockel M, Hogan C, Wu AH, Richards M, Clopton P, Filippatos GS, Di Somma S, Anand I, Ng L, Daniels LB, Neath SX, Christenson R, Potocki M, McCord J, Terracciano G, Kremastinos D, Hartmann O, von Haehling S, Bergmann A, Morgenthaler NG, Anker SD. Mid-region pro-hormone markers for diagnosis and prognosis in acute dyspnea: results from the BACH (Biomarkers in Acute Heart Failure) trial. J Am Coll Cardiol. 2010; 55(19):2062-76. [PubMed: 20447528]

36. Shah RV, Truong QA, Gaggin HK, Pfannkuche J, Hartmann O, Januzzi JL Jr. Mid-regional proatrial natriuretic peptide and pro-adrenomedullin testing for the diagnostic and prognostic evaluation of patients with acute dyspnoea. Eur Heart J. 2012; 33(17):2197-205. [PubMed: 22645194]

37. Januzzi JL Jr, Rehman S, Mueller T, van Kimmenade RR, Lloyd-Jones DM. Importance of biomarkers for long-term mortality prediction in acutely dyspneic patients. Clin Chem. 2010; 56(12):1814-21. [PubMed: 20921266]

38. Bettencourt P, Azevedo A, Pimenta J, Frioes F, Ferreira S, Ferreira A. N-Terminal-Pro-Brain Natriuretic Peptide Predicts Outcome After Hospital Discharge in Heart Failure Patients. Circulation. 2004; 110(15):2168-2174. [PubMed: 15451800]

39. Masson S, Latini R, Anand IS, Barlera S, Angelici L, Vago T, Tognoni G, Cohn JN. Prognostic value of changes in $\mathrm{N}$-terminal pro-brain natriuretic peptide in Val-HeFT (Valsartan Heart Failure Trial). J Am Coll Cardiol. 2008; 52(12):997-1003. [PubMed: 18786480]

40. Masson S, Latini R, Anand IS, Vago T, Angelici L, Barlera S, Missov ED, Clerico A, Tognoni G, Cohn JN. Direct comparison of B-type natriuretic peptide (BNP) and amino-terminal proBNP in a large population of patients with chronic and symptomatic heart failure: the Valsartan Heart Failure (Val-HeFT) data. Clin Chem. 2006; 52(8):1528-38. [PubMed: 16777915]

41. Januzzi JL Jr, Sakhuja R, O’Donoghue M, Baggish AL, Anwaruddin S, Chae CU, Cameron R, Krauser DG, Tung R, Camargo CA Jr, Lloyd-Jones DM. Utility of amino-terminal pro-brain natriuretic peptide testing for prediction of 1-year mortality in patients with dyspnea treated in the emergency department. Arch Intern Med. 2006; 166(3):315-20. [PubMed: 16476871]

42. Eurlings LW, van Pol PE, Kok WE, van Wijk S, Lodewijks-van der Bolt C, Balk AH, Lok DJ, Crijns HJ, van Kraaij DJ, de Jonge N, Meeder JG, Prins M, Pinto YM. Management of chronic heart failure guided by individual N-terminal pro-B-type natriuretic peptide targets: results of the PRIMA (Can PRo-brain-natriuretic peptide guided therapy of chronic heart failure IMprove heart fAilure morbidity and mortality?) study. J Am Coll Cardiol. 2010; 56(25):2090-100. [PubMed: 21144969] 
43. Felker GM, Hasselblad V, Hernandez AF, O'Connor CM. Biomarker-guided therapy in chronic heart failure: a meta-analysis of randomized controlled trials. Am Heart J. 2009; 158(3):422-30. [PubMed: 19699866]

44. Porapakkham P, Zimmet H, Billah B, Krum H. B-type natriuretic peptide-guided heart failure therapy: A meta-analysis. Arch Intern Med. 2010; 170(6):507-14. [PubMed: 20308637]

45. Berger R, Moertl D, Peter S, Ahmadi R, Huelsmann M, Yamuti S, Wagner B, Pacher R. Nterminal pro-B-type natriuretic peptide-guided, intensive patient management in addition to multidisciplinary care in chronic heart failure a 3-arm, prospective, randomized pilot study. J Am Coll Cardiol. 2010; 55(7):645-53. [PubMed: 20170790]

46. Januzzi JL Jr, Rehman SU, Mohammed AA, Bhardwaj A, Barajas L, Barajas J, Kim HN, Baggish AL, Weiner RB, Chen-Tournoux A, Marshall JE, Moore SA, Carlson WD, Lewis GD, Shin J, Sullivan D, Parks K, Wang TJ, Gregory SA, Uthamalingam S, Semigran MJ. Use of aminoterminal pro-B-type natriuretic peptide to guide outpatient therapy of patients with chronic left ventricular systolic dysfunction. J Am Coll Cardiol. 2011; 58(18):1881-9. [PubMed: 22018299]

47. Bhardwaj A, Rehman SU, Mohammed AA, Gaggin HK, Barajas L, Barajas J, Moore SA, Sullivan D, Januzzi JL. Quality of life and chronic heart failure therapy guided by natriuretic peptides: results from the ProBNP Outpatient Tailored Chronic Heart Failure Therapy (PROTECT) study. Am Heart J. 2012; 164(5):793-799. e1. [PubMed: 23137512]

48. Weiner RB, Baggish AL, Chen-Tournoux A, Marshall JE, Gaggin HK, Bhardwaj A, Mohammed AA, Rehman SU, Barajas L, Barajas J, Gregory SA, Moore SA, Semigran MJ, Januzzi JL Jr. Improvement in structural and functional echocardiographic parameters during chronic heart failure therapy guided by natriuretic peptides: mechanistic insights from the ProBNP Outpatient Tailored Chronic Heart Failure (PROTECT) study. Eur J Heart Fail. 2012; 15(3):342-51. [PubMed: 23132825]

49. Gaggin HK, Truong QA, Rehman SU, Mohammed AA, Bhardwaj A, Parks KA, Sullivan DA, Chen-Tournoux A, Moore SA, Richards AM, Troughton RW, Lainchbury JG, Weiner RB, Baggish AL, Semigran MJ, Januzzi JL Jr. Characterization and Prediction of Natriuretic Peptide "Nonresponse" During Heart Failure Management: Results From the ProBNP Outpatient Tailored Chronic Heart Failure (PROTECT) and the NT-proBNP-Assisted Treatment to Lessen Serial Cardiac Readmissions and Death (BATTLESCARRED) Study. Congest Heart Fail. 2013

50. Shah MR, Califf RM, Nohria A, Bhapkar M, Bowers M, Mancini DM, Fiuzat M, Stevenson LW, O'Connor CM. The STARBRITE trial: a randomized, pilot study of B-type natriuretic peptideguided therapy in patients with advanced heart failure. J Card Fail. 2011; 17(8):613-21. [PubMed: 21807321]

51. Persson H, Erntell H, Eriksson B, Johansson G, Swedberg K, Dahlstrom U. Improved pharmacological therapy of chronic heart failure in primary care: a randomized Study of NTproBNP Guided Management of Heart Failure--SIGNAL-HF (Swedish Intervention study-Guidelines and NT-proBNP AnaLysis in Heart Failure). Eur J Heart Fail. 2010; 12(12):1300-8. [PubMed: 20876734]

52. Karlstrom P, Alehagen U, Boman K, Dahlstrom U. Brain natriuretic peptide-guided treatment does not improve morbidity and mortality in extensively treated patients with chronic heart failure: responders to treatment have a significantly better outcome. Eur J Heart Fail. 2011; 13(10):1096103. [PubMed: 21715446]

53. Pfisterer M, Buser P, Rickli H, Gutmann M, Erne P, Rickenbacher P, Vuillomenet A, Jeker U, Dubach P, Beer H, Yoon SI, Suter T, Osterhues HH, Schieber MM, Hilti P, Schindler R, BrunnerLa Rocca HP. BNP-guided vs symptom-guided heart failure therapy: the Trial of Intensified vs Standard Medical Therapy in Elderly Patients With Congestive Heart Failure (TIME-CHF) randomized trial. JAMA. 2009; 301(4):383-92. [PubMed: 19176440]

54. Lainchbury JG, Troughton RW, Strangman KM, Frampton CM, Pilbrow A, Yandle TG, Hamid AK, Nicholls MG, Richards AM. N-terminal pro-B-type natriuretic peptide-guided treatment for chronic heart failure: results from the BATTLESCARRED (NT-proBNP-Assisted Treatment To Lessen Serial Cardiac Readmissions and Death) trial. J Am Coll Cardiol. 2009; 55(1):53-60. [PubMed: 20117364] 
55. Troughton RW, Frampton CM, Yandle TG, Espiner EA, Nicholls MG, Richards AM. Treatment of heart failure guided by plasma aminoterminal brain natriuretic peptide (N-BNP) concentrations. Lancet. 2000; 355(9210):1126-30. [PubMed: 10791374]

56. Jourdain P, Jondeau G, Funck F, Gueffet P, Le Helloco A, Donal E, Aupetit JF, Aumont MC, Galinier M, Eicher JC, Cohen-Solal A, Juilliere Y. Plasma brain natriuretic peptide-guided therapy to improve outcome in heart failure: the STARS-BNP Multicenter Study. J Am Coll Cardiol. 2007; 49(16):1733-9. [PubMed: 17448376] 
Table 1

Cardiac abnormalities associated with natriuretic peptide elevation.

\begin{tabular}{|l|l|}
\hline Characteristic & \\
\hline Myocardial processes & $\begin{array}{l}\text { Systolic dysfunction } \\
\text { Diastolic dysfunction } \\
\text { Fibrosis/scar } \\
\text { Hypertrophy } \\
\text { Infiltrative diseases (amyloidosis) }\end{array}$ \\
\hline Valvular abnormalities & $\begin{array}{l}\text { Mitral stenosis, regurgitation } \\
\text { Aortic stenosis, regurgitation } \\
\text { Tricuspid regurgitation } \\
\text { Pulmonic stenosis }\end{array}$ \\
\hline Cardiac chamber size & $\begin{array}{l}\text { Ventricular enlargement } \\
\text { Atrial enlargement }\end{array}$ \\
\hline Filling pressures & $\begin{array}{l}\text { Atrial, ventricular } \\
\text { Pulmonary }\end{array}$ \\
\hline Ischemic heart disease & Coronary artery ischemia \\
\hline Heart rhythm abnormalities & Atrial fibrillation, flutter \\
\hline Pericardial diseases & Constriction, tamponade \\
\hline Congenital abnormalities & Shunts, stenotic lesions \\
\hline
\end{tabular}


Table 2

Clinical diagnoses other than primary cardiac disease that may be associated with an elevated natriuretic peptide concentration.

\begin{tabular}{|l|l|}
\hline Diagnoses & \\
\hline Anemia & \\
\hline Critical illness & $\begin{array}{l}\text { Sepsis } \\
\text { Burns } \\
\text { Acute respiratory distress syndrome }\end{array}$ \\
\hline Stroke & $\begin{array}{l}\text { Ischemic stroke } \\
\text { Subarachnoid hemorrhage }\end{array}$ \\
\hline Pulmonary heart disease & $\begin{array}{l}\text { Sleep apnea } \\
\text { Pulmonary embolism } \\
\text { Pulmonary hypertension }\end{array}$ \\
\hline Toxic exposures & $\begin{array}{l}\text { Envenomation } \\
\text { Chemotherapy }\end{array}$ \\
\hline
\end{tabular}


Table 3

Important patient-specific factors that may influence natriuretic peptide values.

\begin{tabular}{|l|c|}
\hline Factor & Effect on BNP or NT-proBNP \\
\hline Age & Increase \\
\hline Female sex & Increase \\
\hline Anemia & Increase \\
\hline Renal dysfunction & Increase \\
\hline Obesity & Reduce \\
\hline
\end{tabular}


Table 4

Therapies for HF that may lower natriuretic peptide concentrations.

\begin{tabular}{|l|c|}
\hline Therapy & Effect on BNP or NT-proBNP* \\
\hline Diuresis (loop or thiazide) & Reduce \\
\hline Angiotensin converting enzyme inhibitors & Reduce \\
\hline Angiotensin receptor blockers & Reduce \\
\hline$\beta$-blockers & Reduce \\
\hline Mineralocorticoid receptor antagonists & Reduce \\
\hline Cardiac resynchronization thereapy & Reduce \\
\hline Exercise & Reduce \\
\hline Rate control of atrial fibrillation & \\
\hline
\end{tabular}

It is unclear if the same effects extend to MR-proANP 


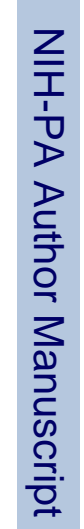

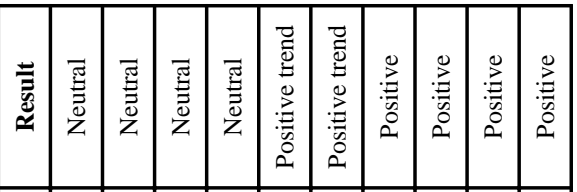

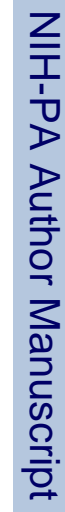

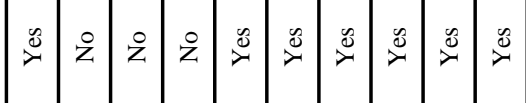

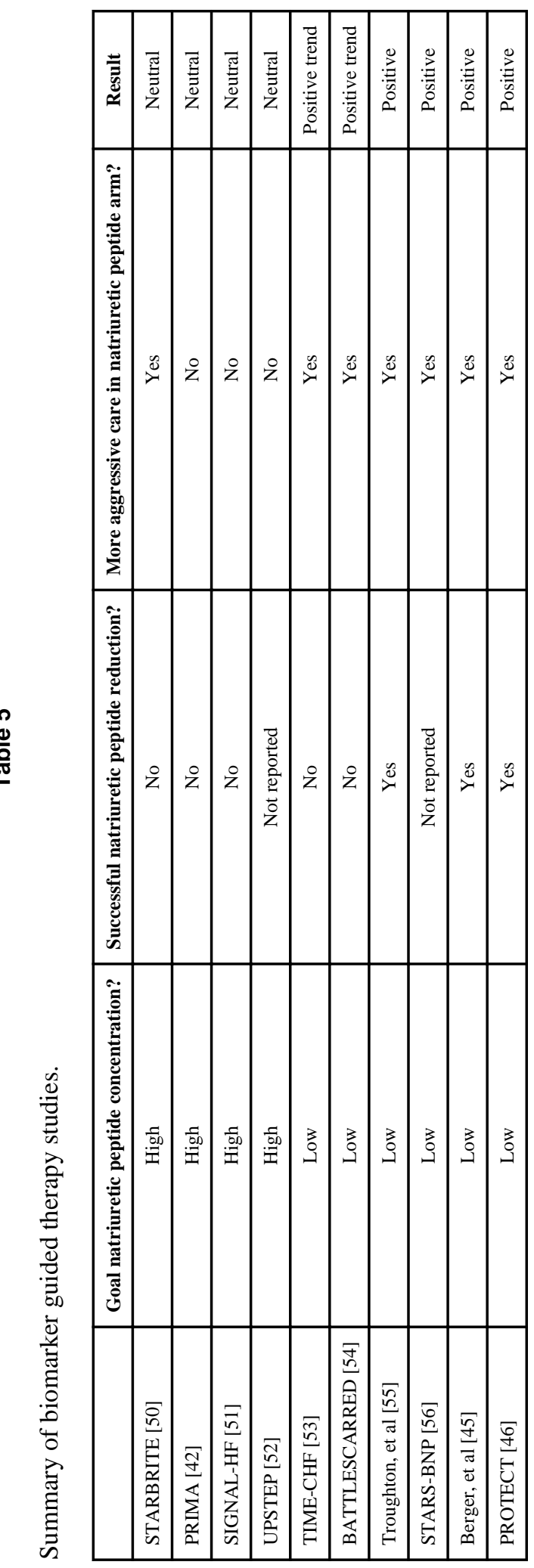

J Investig Med. Author manuscript; available in PMC 2014 August 27. 